\title{
Perkinsus marinus (Apicomplexa) as a potential source of oyster Crassostrea virginica mortality in coastal lagoons of Tabasco, Mexico
}

\author{
Eugene M. Burreson ${ }^{1}$, Raul Sima Alvarez ${ }^{2}$, Victor Vidal Martinez ${ }^{2}$, Leopoldina Aguirre Macedo ${ }^{2}$ \\ 'School of Marine Science, Virginia Institute of Marine Science, College of William and Mary, Gloucester Point, Virginia 23062, USA \\ ${ }^{2}$ Laboratory of Aquatic Pathology, Centro de Investigación y Estudios Avanzados del IPN Unidad Mérida, AP 73 'Cordemex', \\ CP 97310 Mérida, Yucatán, Mexico
}

\begin{abstract}
Poorly documented, but apparently sporadic oyster Crassostrea virginica mortality in the coastal lagoons Carmen, Machona and Mecoacan at the southern extreme of the Gulf of Mexico in Tabasco, Mexico, has been attributed by local oystermen to pollution resulting from oil refinery operations. In September 1992 we sampled oysters in these lagoons to investigate the potential for disease-induced mortality from the oyster pathogen Perkinsus marinus. Prevalence of P. marinus was $100 \%$ at Lodazal, a high salinity (31 ppt) site in Carmen lagoon and $60 \%$ at Rio San Felipe, a low salinity (15 ppt) site. At Los Jimenez, a high salinity (32 ppt) site in Machona lagoon with previous high mortality, prevalence of $P$. marinus was $90 \%$ and weighted prevalence, a measure of intensity, was 3.1, a high value associated with heavy infections and mortality. Samples collected at the Buena Vista aquaculture facility in Mecoacan lagoon revealed 60 to $100 \%$ prevalence of $P$. marinus, although most infections were low intensity. P. marinus is a potential source of oyster mortality in these coastal lagoons; more intensive sampling is necessary to determine the mortality attributable to $P$. marinus.
\end{abstract}

KEY WORDS: Perkinsus marinus - Crassostrea virginica Mortality Immunoassay $\cdot$ Mexico

Carmen, Machona and Mecoacan (Fig. 1) are shallow coastal lagoons at the southern extreme of the Gulf of Mexico in Tabasco, Mexico. These lagoons have very restricted openings to the Gulf of Mexico. Carmen and Machona lagoons may be considered separate embayments in the same lagoon system because they are connected and there are openings to the Gulf of Mexico at each end of the system. The lagoons support intensive and semi-intensive cultures of eastern oysters Crassostrea virginica for local consumption. Oyster spat collectors are placed near the lagoon openings; spat are moved to suspended racks in Mecoacan lagoon and to various bottom locations in Carmen and Machona lagoons.
Recent oyster mortality in these lagoons has been attributed by local oystermen to pollution from oil refinery activities. Mortality is apparently increasing, but is poorly documented. The Mexican oil company Petroleos Méxicanos (PEMEX) has been compensating oystermen for their claimed losses. The situation in Tabasco is very reminiscent of circumstances in the northern Gulf of Mexico in the late 1940s and early 1950 s when the oil industry was blamed for oyster mortality and oil companies funded research that examined the effects of the oil industry on oysters (Reese 1954, Mackin \& Hopkins 1962, Mackin \& Sparks 1962). Field and laboratory investigations by Texas, USA, scientists determined that the oil industry could not be responsible for the widespread mortality and the research eventually resulted in the discovery of the oyster pathogen Perkinsus marinus (Mackin et al. 1950). Subsequent research in the lower Chesapeake Bay by Virginia, USA, scientists revealed that this pathogen was common in areas where there was no oil industry (Andrews 1988).

Perkinsus marinus is a widespread, serious pathogen of eastern oysters Crassostrea virginica. It causes significant oyster mortality throughout the northern Gulf of Mexico and along the east coast of the United States north to Delaware Bay (Andrews 1988, Ford 1992). Drought conditions and unusually warm winters in the middle Atlantic states during the late 1980s allowed the parasite to greatly expand its distribution and abundance within Chesapeake Bay with resultant high oyster mortality (Andrews 1988).

To determine whether pollution from oil operations caused previous, and perhaps continuing, oyster mortality in Tabasco and also to examine other potential sources of mortality, PEMEX has been funding Centro de Investigación y Estudios Avanzados del IPN Unidad 


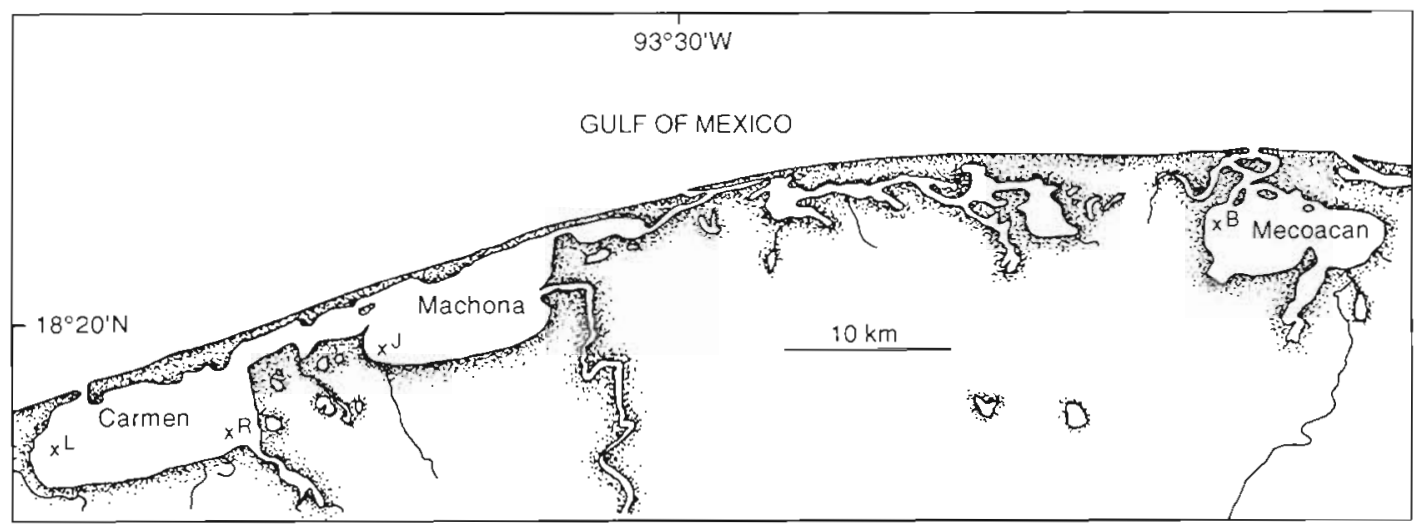

Fig. 1. Sampling locations $(x)$ in coastal lagoons of Tabasco, Mexico L: Lodazal; R: Rio San Felipe; J: Los Jimenez (Stn 32) B: Buena Vista aquaculture facility

Mêrida to conduct various pollution and pathological studies in the lagoons. The Laboratory of Aquatic Pathology has been conducting a histological survey of oysters from both lagoons since July 1992. Slides of oyster tissue containing various parasites were sent to the first author for examination. One slide from an oyster collected in July 1992 from Los Jimenez (Stn 32) in Machona lagoon contained a very heavy infection of a parasite similar to Perkinsus marinus. The first author was invited to Mexico in September 1992 to participate in a survey of oysters in both lagoons to determine the extent of $P$. marinus infections using the thioglycollate culture technique (Ray 1952). This report documents findings of that survey.

Materials and methods. Oysters were collected by various methods on September 16, 1992. In Mecoacan lagoon (Fig. 1) oysters were collected by hand from suspended racks and from the bottom at the Buena Vista aquaculture facility (salinity 15 ppt). In Carmen and Machona lagoons (Fig. 1) oysters were collected by hand tongs from a boat by local oystermen. Samples were collected at a high salinity site (Lodazal, salinity $31 \mathrm{ppt}$ ), and a low salinity site (Rio San Felipe, salinity $15 \mathrm{ppt}$ ) and at an area in Machona lagoon where high mortality had been reported by local oystermen (Stn 32. Los Jimenez, salinity $32 \mathrm{ppt}$ ). Water temperature in the lagoons varies little throughout the year, ranging from 28 to $32^{\circ} \mathrm{C}$.

Oysters were returned to the laboratory at Mérida, Yucatán, where they were shucked. Pieces of mantle, gill and rectum were placed in tubes of fluid thioglycollate medium (FTM) and incubated at $24^{\circ} \mathrm{C}$ in the dark for $5 \mathrm{~d}$. After incubation tissue was removed from the tubes, macerated on a glass slide and a drop of Lugol's iodine added and the tissue covered with a coverglass and examined at $40 \times$ and higher magnification for the presence of Perkinsus organisms. Tubes of sterile FTM had been brought from the U.S. and only 50 tubes were available. Five tubes were used to instruct the co-authors in preparing and reading thio- glycollate assays using oysters collected previousiy Because of the limited number of thioglycollate tubes. only 10 oysters from each sample location were assayed for $P$ marinus and only 5 oysters were assayed from the suspended racks at Buena Vista in Mecoacan lagoon. Infections were rated as negative, light, moderate or heavy (Ray 1954) and assigned ratings of 0,1 , 3 or 5 respectively for calculation of weighted prevalence (WP) (Mackin 1962). WP combines prevalence and intensity into a single expression and is determined by adding the individual assigned values and dividing by the number of oysters sampled. WP values less than 1.0 indicate mostly light infections with little or no mortality (Andrews 1988). Values greater than 2.0 indicate high prevalence and many severe infections with the potential for high mortality.

The remaining tissue from the oysters collected at Los Jimenez in Machona lagoon was preserved in Davidson's AFA and returned to Virginia for histological and immunoassay analysis. A section through the visceral mass of each preserved oyster that contained mantle, gill and digestive gland was embedded in paraffin, cut at $5 \mu \mathrm{m}$ thickness and affixed to glass slides. For histological analyses sections were processed according to standard techniques and stained with Harris' hematoxylin and eosin (HHE).

Immunoassays were conducted with anti-Perkinsus marinus polyclonal antibody to determine if the Perkinsus-like parasite was antigenically similar to $P$. marinus Antibody was generously supplied by C. F. Dungan, Cooperative Oxford Laboratory, Oxford, MD, USA. Production and specificity of the antibody is described by Dungan \& Roberson (1993). Biocell goat anti-rabbit IgG gold probe and Biocell light microscopy silver enhancement reagents (Goldmark Biologicals, Phillipsburg. NJ, USA) were utilized to visualize specific binding of the primary antibody. For immunoassay, 3 consecutive $5 \mu \mathrm{m}$ sections were affixed to separate glass slides, dewaxed in xylene, and hydrated in a graded ethanol series to water. One of the 3 slides was stained with Harris' 
hematoxylin and eosin (HHE). The remaining 2 slides were washed in running tap water and phosphate buffered saline (PBS) and blocked for $30 \mathrm{~min}$ with $10 \% \mathrm{v} / \mathrm{v}$ normal goat serum in phosphate buffered saline containing $1.0 \%$ bovine serum albumin (PBSA). After blocking, 1 of the 2 slides was incubated for $30 \mathrm{~min}$ in a 1:100 dilution of primary antibody in PBSA. The other slide, the negative control, was incubated for $30 \mathrm{~min}$ in a 1:100 dilution of normal rabbit serum in PBSA. The slides were then washed in PBS and incubated for $1 \mathrm{~h}$ in a 1:100 dilution of affinity-purified goat anti-rabbit IgG coated onto $5 \mathrm{~nm}$ colloidal gold particles in PBSA. After thorough washing in PBS and distilled water, bound colloidal gold particles were visualized with silver enhancement reagents that produced a brown to black color. Slides were then washed in distilled water, counter stained with fast green, dehydrated in ethanol, cleared in xylene and coverslipped

Results. Parasites that reacted positively in thioglycollate assays were found at all locations sampled. Spherical, bluish-grey to black cells were observed, typical of Perkinsus marinus. Prevalence and weighted prevalence determined by thioglycollate assay for each sample location are shown in Table 1. Prevalence was at least $60 \%$ at all stations and was $100 \%$ in oysters on the bottom at Buena Vista in Mecoacan lagoon and at Lodazal in Carmen lagoon. There were moderate infection intensities at all locations except the low salinity area of Rio San Felipe in Carmen lagoon; heavy infection intensities were observed only at Los Jimenez in Machona lagoon and in bottom oysters at Buena Vista in Mecoacan lagoon.

Histological preparations of the very heavily infected oyster collected in July 1992 from Los Jimenez (Stn 32) that were originally sent to the first author revealed large concentrations of small meront stages in hemocytes in the gut epithelium and throughout the connective tissue (Fig. 2). Large portions of the gut epithelium (Fig. 2) and of the gonad were completely destroyed by the parasite in this oyster. Histological analyses of oysters collected in September 1992 from the same location revealed Perkinsus marinus prevalence of $60 \%$, typically lower than the more sensitive thioglycollate assay at the same location (see Table 1). Infections consisted of small meronts primarily in hemocytes in the gut epithelium (Figs. $3 \& 4$ ), although one oyster with a heavier infection also had a gonad lesion (Figs. 5 \& 6).
Parasite diameter in all infections ranged from 1.0 to $8.0 \mu \mathrm{m}$, but most cells were small, 1.0 to $3.0 \mu \mathrm{m}$ in diameter. Large meronts with typical signet-ring morphology were not observed. These small meronts reacted positively in immunoassays using antiPerkinus marinus antibody (Figs. 3 \& 5). Meronts were black, typical of the colloidal gold/silver enhancement visualization technique and easily visible against the fast green counterstain

Discussion. Results of the thioglycollate assays and immunoassays suggest that the parasite observed in oysters in Tabasco is Perkinsus marinus. The presence of $P$. marinus in the southern Gulf of Mexico is certainly not surprising considering that most Perkinsus species occur in tropical to subtropical regions and that the pathogen was known previously to be widespread in the northern Gulf of Mexico south to Tampico, Mexico (Mackin 1962). Craig et al. (1989) found P. marinus in all 49 sites surveyed from Florida to southern Texas, but both prevalence and intensity were highest along the southwest coast of Florida where water temperature was highest. The authors attributed the greater abundance of the parasite in these areas to higher temperature for longer periods and their data support similar conclusions by Quick \& Mackin (1971). Ray (1954) indicated that the maximum development of $P$. marinus occurs at temperatures above $25^{\circ} \mathrm{C}$. Thus high prevalence and intensity of $P$. marinus would be expected in the coastal lagoons of Tabasco (assuming favorable salinity) because water temperature is always above $25^{\circ} \mathrm{C}$ and is even higher than in southwestern Florida.

Salinity is also an important controlling factor for Perkinsus marinus; values above 12 to 15 ppt are required for parasite development (Andrews 1988, Ragone \& Burreson 1993). During our study prevalence and weighted prevalence, a measure of intensity, 


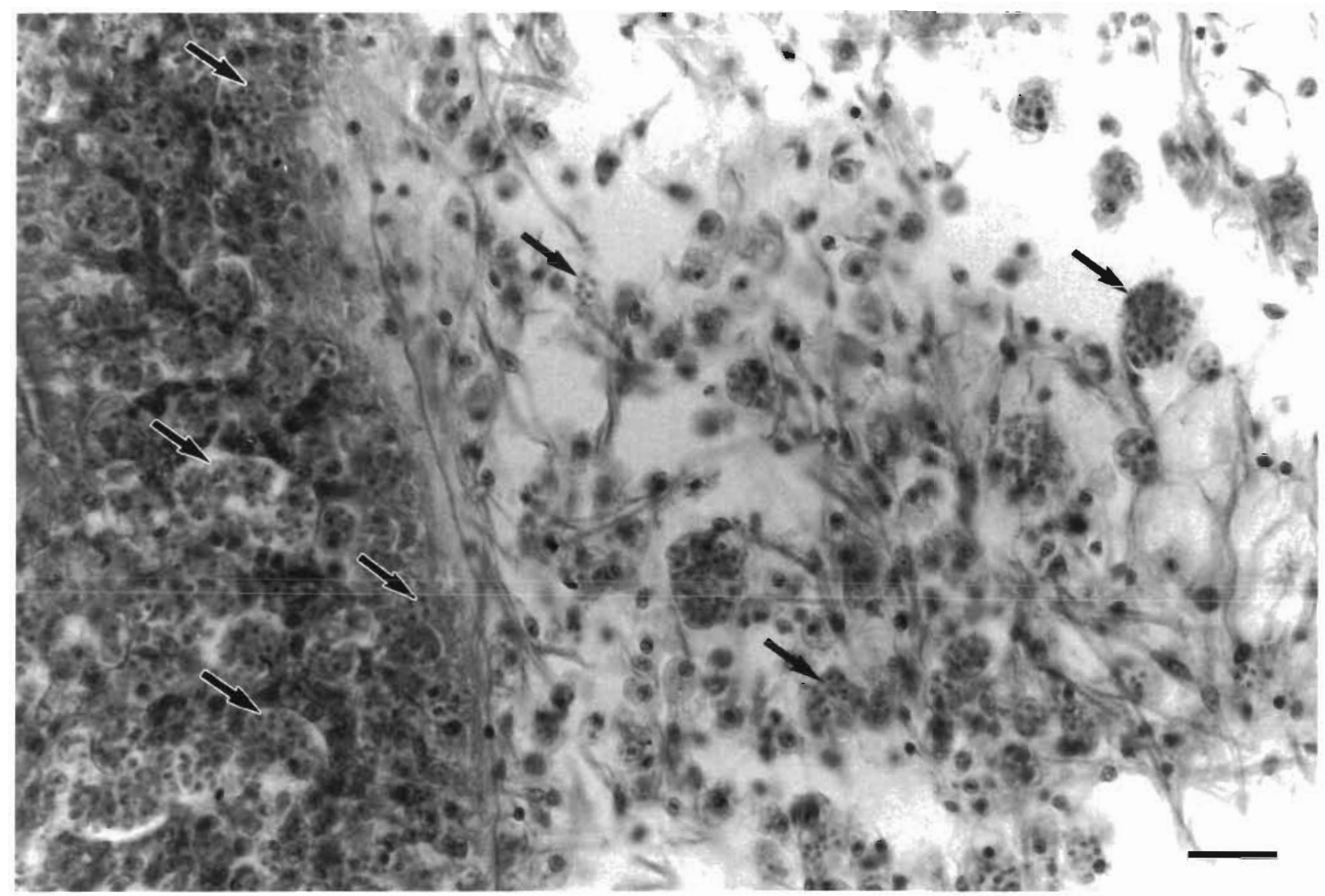

Fig. 2. Perkinsus marinus in Crassostrea virginica. Heavy infection of stomach epithelium (left) and adjacent connective tissue of oysters from Los Jimenez (Stn 32) in Machona lagoon. HHE stain. A few of the many aggregations of $P$. marinus are indicated by arrows. Scale bar $=10.0 \mu \mathrm{m}$

were highest at Los Jimenez in Machona lagoon, the site with highest salinity. Prevalence and intensity were also high at Lodazal in Carmen lagoon where salinity was also high and in the bottom sample from Buena Vista, where salinity was 15 ppt at sampling. The high prevalence and the presence of moderate and heavy infections at Buena Vista even though salinity was not high is not necessarily surprising because the seasonal cycle and recent history of $P$. marinus infections at this site are not known.

The high prevalence and intensity of Perkinsus marinus at certain locations within the lagoons in Tabasco and its known pathogenicity in other areas (Andrews 1988, Burreson 1991) suggest that this parasite may be responsible for oyster mortality in Mexico. However, during this study, sample size was small and only 4 oyster beds were sampled in the 3 lagoons. No definitive conclusions can be reached until a much better assessment can be made of the extent and temporal variation of oyster mortality and of the temporal and spatial prevalence and intensity of $P$. marinus. Oyster mortality from sources other than $P$. marinus cannot be excluded at this time. Additional field and laboratory investigation is needed to determine the role of $P$. marinus in local oyster mortality. Samples need to be collected at least bimonthly over a 2 yr period from fixed sampling locations and analyzed for $P$. marinus in conjunction with environmental parameters and documented oyster mortality. Nonetheless, on the basis of experience in other areas, $P$. marinus probably is responsible for more oyster mortality in Tabasco than oil pollution.

Acknowledgements. This research and travel was funded by PEMEX through a grant to CINVESTAV-IPN Unidad Mérida The authors thank Dr Gerardo Gold for his support, guidance and for comments on the manuscript. José Oseguera of PEMEX was a gracious host in Villahermosa, Tabasco and arranged for helicopter support for sampling. In Mexico, thanks to research assistant Jorge Güemez and Gregory Arjona Torres who provided histological support. In Virginia, Juanita Walker provided histological support and Lisa Ragone Calvo conducted the immunoassays using antibody provided by C. F. Dungan, Cooperative Oxford Laboratory, Maryland. E.M.B. thanks Victor and Leopoldina for being such gracious hosts in Mexico. VIMS contribution number 1892 

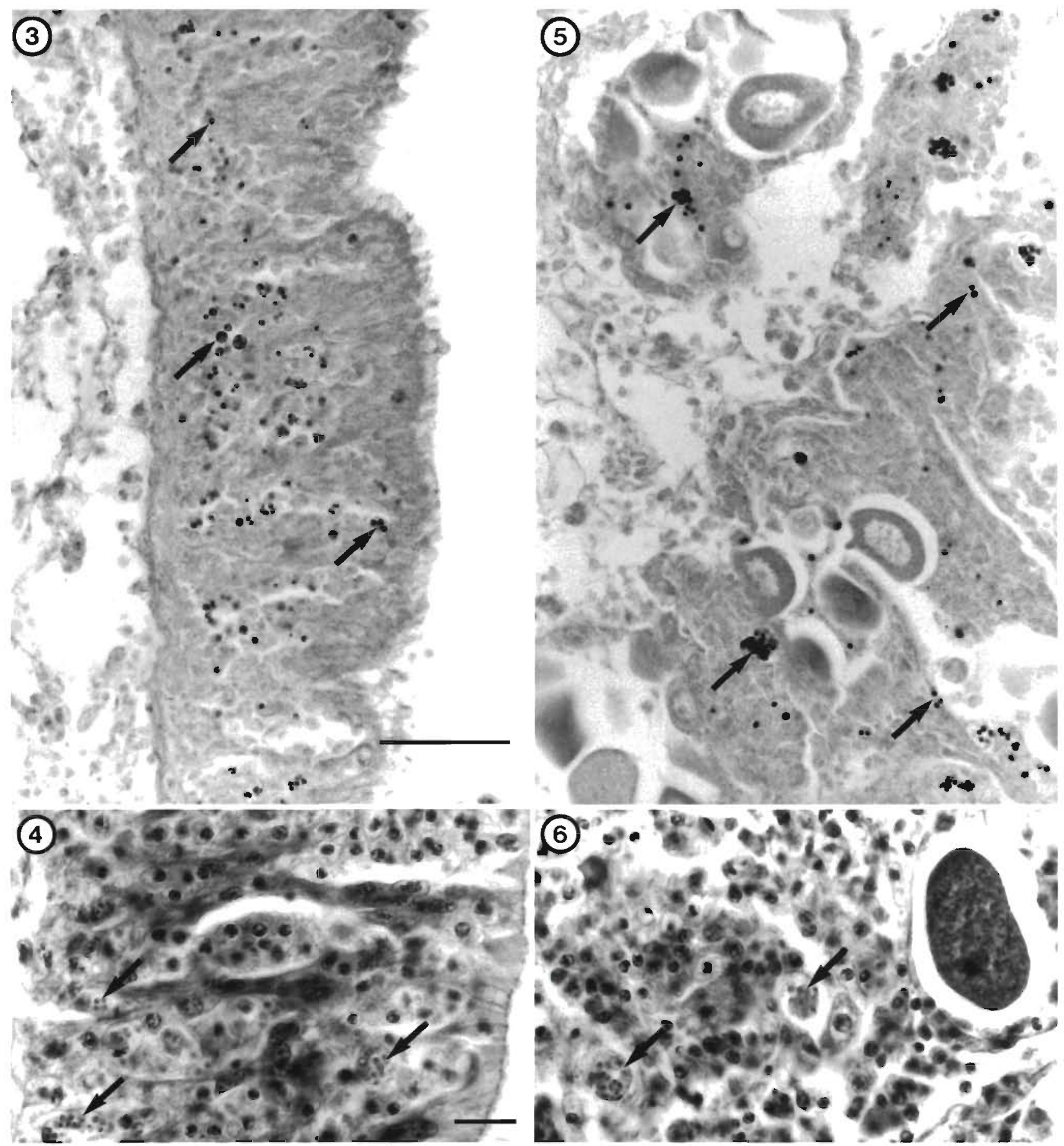

Figs 3 to 6. Perkinsus marinus infecting Crassostrea virginica. Fig. 3. P. marinus meronts in stomach epithelium visualized by anti- $P$. marinus antibody; only a few of the many cells are indicated by arrows. Scale bar $=50 \mu \mathrm{m}$. Fig. 4 . Detail of stomach epithelium showing meronts (arrows). HHE stain. Scale bar $=12.0 \mu \mathrm{m}$. Fig. 5. Meronts in gonad lesion visualized by antiP. marinus antibody; only a few of the many cells are indicated by arrows. Scale as in Fig. 3. Fig. 6. Detail of gonad lesion showing meronts (arrows). HHE stain. Scale as in Fig. 4 


\section{LITERATURE CITED}

Andrews, J. D. (1988). Epizootiology of the disease caused by the oyster pathogen Perkinsus marinus and its effects on the oyster industry. Am. Fish. Soc. spec. Publ. 18: 47-63

Burreson, E. M. (1991). Effects of Perkinsus marinus infection in the eastern oyster, Crassostrea virginica: I. Susceptibility of native and MSX-resistant stocks. J. Shellfish Res. 10: $417-423$

Craig, A., Powell, E. N., Fay, R. R., Brooks, J. M. (1989). Distribution of Perkinsus marinus in Gulf coast oyster populations. Estuaries 12: 82-91

Dungan, C. F., Roberson, B. S. (1993). Binding specificities of mono- and polyclonal antibodies to the protozoan oyster pathogen Perkinsus marinus. Dis. aquat. Org. 15: 9-22

Ford, S. E. (1992). Avoiding the transmission of disease in commercial culture of molluscs, with special reference to Perkinsus marinus (Dermo) and Haplosporidium nelsoni (MSX). J. Shellfish Res. 11: 539-546

Mackin, J. G. (1962). Oyster diseases caused by Dermocystidium marinum and other microorganisms in Louisiana. Publs. Inst. mar. Sci. Univ. Tex. 7: 132-229

Mackin, J. G., Hopkins, S. H. (1962). Studies on oyster mortality in relation to natural environments and to oil

Responsible Subject Editor: A. K. Sparks, Seattle, Washington, USA fields in Louisiana. Publs. Inst. mar. Sci. Univ. Tex. 7 : $1-131$

Mackin, J. G., Owen, H. M., Collier, A. (1950). Preliminary note on the occurrence of a new protistan parasite, Dermocystidium marinum n. sp. in Crassostrea virginica (Gmelin). Science 111: 328-329

Mackin, J. G., Sparks, A. K (1962). A study of the effects on oyster of crude oil loss from a wild well. Publ. Inst. mar Sci. Univ. Tex. 7: 230-319

Quick, J. A., Mackin, J. G. (1971). Oyster parasitism by Labyrinthomyxa marina in Florida. Florida Dept Nat. Resources, Mar. Res. Lab. Prof. Pap. Ser. 13: 1-55

Ragone, L. M., Burreson, E. M. (1993). Effect of salinity on infection progression and pathogenicity of Perkinsus marinus in the eastern oyster, Crassostrea virginica (Gmelin). J. Shellfish Res. 12: 1-7

Ray, S. M. (1952). A culture technique for the diagnosis of infections with Dermocystidium marinum, Mackin. Owen and Collier, in oysters. Science 166: 360-361

Ray, S. M. (1954). Biological studies of Dermocystidium marinum. Rice Inst. Pamphlet, Spec. Issue. The Rice Institute, Houston

Reese, A. (1954). Oil lends a hand to the bayou bcastic. World Oil (May): $1-6$

Manuscript first received: December 16, 1993

Revised version accepted: May 27, 1994 